\section{US biotech in good health}

\section{Washington} commercial exploitation of biotechnology, but progress in the development and marketing of new products made through biotechnology has been slower than expected, according to a report* released this week by the congressional Office of Technology Assessment (OTA). The report emphasizes that the key to maintaining a competitive position in the world marketplace depends less on the targeted sponsorship of biotechnology by the federal government and more on a strong research base.

In fiscal year 1990, the federal government spent more than $\$ 3,400$ million to support research and development in biotechnology-related areas, more than 80 per cent of which was awarded through the National Institutes of Health. According to OTA, biotechnology-based drug development is flourishing. To date, 15 drugs and other biological products have been approved by the US Food and Drug Administration (FDA), and more than 100 others are in various stages of development. And 1991 has been the best year since the stock market crash of October 1987 for biotechnology companies hoping to raise capital in the public markets.

Despite this rosy picture, OTA reports that the commercialization of biopharmaceutical products developed using biotechnology has been slower than expected and that the impact of biotechnology on other sectors of industry - agriculture, the chemical industry and the environmental business - has been limited.

OTA notes that six years after the Coordinated Framework for Regulation of Biotechnology was first proposed and four a disincentive to investment. sured by targeting alone.
The United States is still number one in the

years after it was made final, regulations for genetically modified pesticides and certain microorganisms are still not in place. This failure has led industry representatives to complain that the approval process as it stands is unclear and serves as

Other policy issues singled out by OTA as relevant to US competitiveness include the need to structure coherent tax policies and adequately protect intellectual property rights. As markets in biotechnology become increasingly global, OTA says that protection of intellectual property is likely to become less of a domestic issue and more of an international one.

Despite the fact that in 1981 Japan's Ministry of International Trade and Industry singled out biotechnology as a key technology for the future, OTA reports that Japan's weak publicly funded research base has led companies there to look for research and training abroad, notably in the United States. OTA concludes that increased competitiveness cannot be as-

OTA predicts that in the near term ( 5 to 10 years), the European Community, with its traditional strengths in pharmaceuticals and agriculture, poses the greatest threat to US competitiveness in biotechnology. However, a fragmented research effort, adverse public opinion surrounding biotechnology and the uncertain effects of recently introduced Community directives on the contained use and deliberate release of genetically modified organisms could hold Europe back.

Although some foreign companies are actively investing in US biotechnology companies, OTA says that approximately 75 per cent of all mergers and acquisitions

\section{SOVIET SPACE}

\section{Mars projects still alive}

Moscow

REPORTS of the demise of the Soviet space programme notwithstanding, the exploration of Mars remains a top priority. The plan is that there should be four consecutive visits to Mars by instrumented space probes in 1994, 1996, 1998 and 2001. The smaller of two Mars-landing vehicles, called Marsokhods, has already been tested successfully on the Kamchatka Peninsula, at an outstation of the St. Petersburg Transport Machine-Building Institute.

The volcanic terrain of Kamchatka is believed to resemble that of Mars, but the testing of the $75-\mathrm{kg}$ vehicle was interrupted in the summer by torrential rain, of which there is none on Mars. Further tests are planned in the Mojave Desert in the United States in May next year.

The smaller vehicle is planned for the
1998 mission, and the larger, with a mass of between 400 and $500 \mathrm{~kg}$, for the mission in 2001. Both are designed on the same principles, with six driven wheels mounted on a flexible chassis. The wheels, which carry terrain-matching devices on their surfaces for reliable traction, are conical-cylindrical in shape and so elongated that, on the smaller vehicle, there is no gap between them.

Vitali Vernigora, from the Babakin Research and Test Centre in Moscow and one of the designers, says the Mars landers are designed to navigate all terrains and to clamber over obstacles in their way. Because of the distance between the Earth and Mars, it will be necessary for them to function semi-autonomously on the surface of Mars, travelling along preset paths loaded into their computers. Yuri Kanin are between companies based in the United States, as illustrated by the $\$ 660$ million merger of Chiron and Cetus and, more recently, the acquisition of a 60 per cent stake in Genetics Institute by American Home Products.

Diane Gershon

*US Congress, Office of Technology Assessment, Biotechnology in a Global Economy, OTA-BA-494 (Washington, D.C.: US Government Printing Office, October 1991).

\section{HUMAN GENOME PROJECT}

\section{Tit for tat on patents?}

\section{London}

IF US National Institutes of Health researcher Craig Venter is successful in his attempt to patent 337 partially sequenced human genes (see Nature 353,485 ; 10 October 1991), international relations among genome researchers will never be the same.

Tony Vickers, who manages the UK Medical Research Council's (MRC) Human Genome Mapping Project, says that, should Venter's US patent application succeed, British researchers would be forced reluctantly to follow suit, ending the MRC's policy of making its cDNA sequences available to all researchers free of charge. A decision in favour of Venter's application would be "seriously prejudicial to the whole thrust of the international Human Genome Project," Vickers says.

"We don't believe that there's anything inherently patentable in one of these fragmentary cDNA pieces," says Vickers. But if the US Patent Office decides otherwise "the [British] government will say: 'What are you doing standing around?"'

The sequences produced by Venter are for fragments of human genes, each consisting of several hundred bases from a gene that may contain thousands. These partial sequences may yield enough information to guess at the function of the genes from which they come. Vickers believes the inventive step lies in discovering a gene's function, and putting this knowledge to use, rather than in simply producing a partial sequence.

A successful patent application by Venter would bring the ugly prospect of patent disputes dividing the international genome community. Under US law, patents are awarded to the first to invent, rather than simply the first to file an application (if the initial inventor files within one year of an other earlier application). Vickers is convinced that Venter must have sequenced some of the same genes contained in the MRC's sequence database.

In France, the home of Europe's other major cDNA sequencing effort, genome project officials are similarly taken aback by Venter's move. According to an aide to Jacques Hanoune of the French medical research agency INSERM, who runs the French government's genome project, the French are now considering applying for their own patents, although no decision has yet been made.

Peter Aldhous 